\title{
PERLINDUNGAN HUKUM \\ TERHADAP WARGA NEGARA INDONESIA NON-PRIBUMI UNTUK MEMPEROLEH KEPASTIAN HAK MILIK
}

\author{
Riza Anggun Listya Irawan \\ Magister Kenotariatan Fakultas Hukum Universitas Brawijaya \\ Jl. MT. Haryono No. 169 Malang \\ riza.listya@gmail.com
}

\begin{abstract}
The ownership of the land ownership in Yogyakarta City is different from other regions because of the implementation of the 1975 DIY Regional Head Instruction on Uniform Policy of Land Rights Provision to a NonIndigenous Indonesian Citizen. As a result Citizens of Chinese descendants residing in the city of Yogyakarta cannot have ownership rights to the land and it is contrary to the principle of nationality in the UUPA which asserts that all citizens can have ownership rights to land in Indonesia without discriminating one's race or ethnicity. The research method used is empirical juridical research. The dominant factor underlying the difficulties of Chinese citizenship to own property rights to land is caused by the factor of Legal Culture in Yogyakarta City. Prohibition of granting property rights to land for Chinese Citizens resulted in impediments in the implementation of rights and obligations to be performed. Regulations that allow citizens of Chinese descent to be able to own land rights in Yogyakarta City but with restrictions such as the area of land that can be purchased.
\end{abstract}

Keywords: Legal Protection, Indonesian citizens non-natives, Land Ownership.

\begin{abstract}
ABSTRAK
Penguasaan hak milik atas tanah di Kota Yogyakarta berbeda dibandingkan daerah lain, karena masih diberlakukannya Instruksi Kepala Daerah DIY tahun 1975 tentang Penyeragaman Kebijakan Pemberian Hak Atas Tanah Kepada Seorang WNI Nonpribumi. Akibatnya WNI Keturunan Tionghoa yang bertempat tinggal di Kota Yogyakarta tidak dapat mempunyai hak milik atas tanah dan hal tersebut bertentangan dengan asas nasionalitas didalam UUPA yang menegaskan bahwa semua WNI dapat mempunyai hak milik atas tanah di Indonesia tanpa membedaka ras atau suku seseorang. Metode penelitian yang digunakan adalah penelitian yuridis empiris. Faktor dominan yang mendasari sulitnya WNI Keturunan Tionghoa untuk mempunyai hak milik atas tanah disebabkan oleh faktor Budaya Hukum di Kota Yogyakarta, Larangan pemberian hak milik atas tanah bagi WNI Keturunan Tionghoa mengakibatkan terhambatnya pelaksanaan hak dan kewajiban yang harus dilakukan. Peraturan yang tetap memperbolehkan WNI Keturunan Tionghoa untuk dapat mempunyai hak milik atas tanah di Kota Yogyakarta tetapi dengan pembatasan seperti luas tanah yang dapat dibeli.
\end{abstract}

Kata Kunci: Perlindungan Hukum, WNI non pribumi, kepemilikan tanah. 
Penguasaan hak atas tanah di Provinsi Daerah Istimewa Yogyakarta (selanjutnya disebut DIY) yang terdiri dari 4 (empat) kabupaten dan 1 (satu) kota yaitu Kabupaten Bantul, Kabupaten Gunungkidul, Kabupaten Kulon Progo, Kabupaten Sleman dan Kota Yogyakarta memiliki peraturan yang berbeda dibandingkan daerah lain, yakni masih adanya penggunaan istilah Warga Negara Indonesia Pribumi (selanjutnya disebut WNI Pribumi) dan Warga Negara Indonesia non Pribumi (selanjutnya disebut WNI non Pribumi) dalam hal penguasaan hak atas tanah di DIY, dimana WNI non Pribumi Keturunan Tionghoa (untuk selanjutnya disebut WNI keturunan Tionghoa) tidak diperbolehkan untuk mempunyai Hak Milik atas tanah di Yogyakarta (Nur Aini, 2011, 41).

Contoh kasus terjadi pada Bapak Goenawan di Jalan Kusumanegara Kota Yogyakarta bahwa tanah hak milik yang dibelinya pada Agustus 2015 dari seorang WNI Pribumi asli Kota Yogyakarta, tidak akan diproses permintaan balik nama sertifikat tersebut oleh Kantor Pertanahan Kota Yogyakarta sebelum Bapak Goenawan melakukan pelepasan hak yang nantinya akan diberikan hak lain berupa HGB/ HP dengan jangka waktu 30 tahun. Kepala Kantor Wilayah Badan Pertanahan Nasional Yogyakarta, Arie Yuwirin juga menegaskan bahwa keseluruhan WNI keturunan yang tinggal di DIY tidak diperbolehkan untuk memiliki hak berupa hak milik atas tanah di Kota Yogyakarta.

Ketentuan pembedaan istilah WNI dan larangan kepemilikan tersebut diperkuat seiring dengan masih diberlakukannya Instruksi Kepala Daerah Istimewa Yogyakarta PA.VIII/No.K.898/ I/ A 1975 tentang Penyeragaman Policy Pemberian Hak Atas Tanah Kepada Seorang WNI Nonpribumi (Ariesta, 2014, 1), yang berisikan:

Guna penyeragaman policy pemberian hak atas tanah dalam wilayah Daerah Istimewa Yogyakarta kepada seorang WNI non Pribumi, dengan ini diminta: Apabila ada seorang WNI non Pribumi membeli tanah hak milik rakyat, hendaknya diproseskan sebagaimana biasa, ialah dengan melalui pelepasan hak, sehingga tanahnya kembali menjadi tanah Negara yang dikuasai langsung oleh Pemerintah Daerah DIY dan kemudian yang berkepentingan/ melepaskan supaya mengajukan permohonan kepada Kepala Daerah DIY untuk mendapatkan suatu hak.

Hal tersebut bertentangan dengan kebijaksanaan nasional di bidang pertanahan yaitu asas nasionalitas Pasal 9 dan Pasal 21 Ayat 1 UUPA yang menyatakan bahwa subyek hukum yang dapat memperoleh hak milik atas tanah di Indonesia hanya Warga Negara Indonesia, sebagaimana yang diakui oleh Undang-Undang tentang Kewarganegaraan tahun 2006, khususnya Pasal 2. Bentuk kepastian hukum yang diberikan oleh Pemerintah kepada WNI yaitu dengan dibuatkan bukti identitas warga negara berupa Kartu Tanda Penduduk Republik Indonesia disertai Nomor Induk Kependudukan yang akan diberikan pada saat seseorang mencapai usia 17 tahun. Jika dikaitkan dengan syarat kepemilikan hak milik atas tanah maka tentu semua WNI berhak untuk memiliki suatu hak atas tanah dengan status Hak Milik, tanpa terkecuali warga keturunan Tionghoa.

Sikap tersebutlah yang secara tidak langsung menimbulkan perbedaan dan melanggar ketentuan HAM yang mengatur mengenai hak untuk bebas mempunyai hak milik serta bebas dari segala bentuk perbuatan atau perlakuan yang diskriminatif, sebagaimana yang disebutkan dalam Pasal 40 Undang-Undang Nomor 39 Tahun 1999 tentang Hak Asasi Manusia (selanjutnya disebut UU HAM) bahwa setiap orang berhak untuk bertempat tinggal serta berkehidupan yang layak. Karena memang didalam Instruksi tersebut tidak dijelaskan terkait dengan dasar-dasar atau alasan hukum kenapa seorang WNI Keturunan Tionghoa tidak diperbolehkan memiliki hak milik atas tanah di DIY, melainkan hanya demi melindungi warga pribumi 
dari golongan yang memiliki finansial lebih tinggi (WNI Keturunan Tionghoa).

Padahal dalam kenyataan sosial yang ada, tidak seluruhnya warga keturunan Tionghoa merupakan warga yang memiliki kelebihan finansial atau tergolong pemodal kuat, sebagaimana halnya tidak seluruh warga asli merupakan kelompok ekonomi lemah. Menurut Komnas HAM RI $(2013,1)$ pembatasan atau pengurangan hak atas kepimilikan tanah tidak dapat didasarkan pada pertimbangan etnisitas dan segi finansial seseorang. Penelitian tentang isi dalam Instruksi Kepala Daerah DIY tahun 1975 perlu kembali dikaji, karena bagaimanapun WNI Keturunan Tionghoa juga berkedudukan sebagai WNI dan juga memiliki hak dan kewajiban yang sama sebagai warga negara.

Berdasarkan latar belakang di atas dapat dirumuskan 3 rumusan masalah pertama, faktor dominan yang menyebabkan sulitnya WNI Keturunan Tionghoa memperoleh hak milik atas tanah di Kota Yogyakarta. Kedua, akibat hukum dari larangan pemberian hak milik atas tanah bagi WNI Keturunan Tionghoa di Kota Yogyakarta. Ketiga, upaya yang seharusnya dilakukan oleh Gubernur DIY dalam memberikan perlindungan hukum bagi WNI Keturunan Tionghoa guna memperoleh hak milik atas tanah melalui jual beli.

\section{Metode Penelitian}

Jenis penelitian ini adalah penelitian yuridis empiris, yaitu untuk mengkaji pelaksanaan perlindungan hukum bagi WNI Keturunan Tionghoa terkait dengan larangan pemberian hak miik atas tanah di Kota Yogyakarta, sebagaimana yang terdapat dalam Instruksi Kepala DIY PA.VIII/ No.K.898/I/A 1975 tentang Penyeragaman Policy Pemberian Hak Atas Tanah Kepada Seorang WNI non Pribumi. Pendekatan yang digunakan untuk menganalisis permasalahan dalam penelitian ini adalah pendekatan yuridis sosiologis yang bertujuan untuk mengkaji kaidah-kaidah hukum yang ada di dalam Instruksi Kepala Daerah DIY PA.VIII/No.K.898/I/ A 1975, kemudian dilihat dari aspek pelaksanaan peraturan tersebut di DIY hingga didapatkan kesimpulan terkait bagaimana sebuah peraturan perundangan-undangan digunakan dalam masyarakat.

Jenis dan sumber data dalam penelitian ini adalah data primer dan data sekunder. Teknik analisa data yang digunakan dalam penelitian ini adalah teknik analisis deskriptif kualitatif, yakni teknik mendeskripsikan dan menganalisis datadata yang diperoleh dilapangan dan selanjutnya data-data tersebut akan dianalisis dengan mengkaitkan teori-teori hukum berupa teori efektifitas penegakan hukum, teori kepastian hukum, teori pemilikan tanah dan teori perlindungan hukum.

\section{Pembahasan}

1. Faktor Dominan yang Menyebabkan Sulitnya WNI Keturunan Tionghoa Memperoleh Hak Milik Atas Tanah

Pemberlakuan UUPA pada tahun 1960 adalah bentuk keseriusan pemerintah untuk menciptakan unifikasi hukum yang ada dalam hal pertanahan di Indonesia menjadi satu bentuk aturan dasar dan berlaku bagi semua wilayah yang ada di Republik Indonesia. Namun masih ada daerah di Indonesia yang belum bisa menerapkan UUPA secara efektif, seperti yang terjadi di Kota Yogyakarta dimana WNI Keturunan Tionghoa masih mengalami kesulitan dalam mengakses hak konstitusionalnya sebagai warga negara untuk dapat memperoleh hak milik atas tanah. Teori efektifitas penegakan hukum Soerjono Soekanto $(1983,143)$ digunakan untuk menganalisis faktorfaktor apa yang mempengaruhi sulitnya WNI Keturunan Tionghoa memperoleh hak milik atas tanah di Kota Yogyakarta, dan setelah dianalisis berdasarkan data-data dilapangan didapatkan ketiga faktor dibawah ini yaitu: 
a. Substansi.

Masih diberlakukannya Instruksi Kepala Daerah DIY PA. VIII/ No.K.898/ I/ A/ 1975 tentang Penyeragaman Policy Pemberian Hak Atas Tanah Kepada Seorang WNI Nonpribumi, mengakibatkan WNI Keturunan Tionghoa yang tinggal dan berdomisili di wilayah Yogyakarta mengalami kesulitan untuk memperoleh hak milik atas tanah. Apabila dilihat secara yuridis, mekanisme yang dilakukan untuk memperoleh hak milik atas tanah telah dilakukan secara benar, karena UUPA menganut asas Nasionalitas dimana hak milik atas tanah yang ada di Republik Indonesia hanya dapat dimiliki oleh orang Indonesia dengan kewarganegaraan tunggal.

Proses peralihan hak milik yang sering terjadi yaitu melalui jual beli, dimana akan terjadi peralihan subyek pemegang hak milik dari pemilik awal kepada pemillik yang baru. Selanjutnya proses yang dilakukan adalah pendaftaran tanah, tujuannya untuk melakukan perubahan penyesuaian data terhadap sertifikat bukti kepemilikan tanah. Proses saat pendaftaran tanah inilah yang akhirnya menjadi masalah di Kota Yogyakarta.

Berdasarkan hasil penelitian di Kantor Pertanahan Kota Yogyakarta WNI Keturunan Tionghoa dalam pelayanan pertanahan tidak dapat diberikan HM atas tanah, dan diharuskan untuk melakukan penyerahan hak yang bisa dilakukan dengan proses lepasan hak/ penurunan hak terlebih dahulu sehingga nantinya dapat diberikan hak baru berupa HGB/ HP. Aturan tersebut berlaku bagi semua pelayanan pertanahan baik itu: pengajuan permohonan pendaftaran hak atas tanah untuk pertama kali, peralihan, perpanjangan ataupun pembaharuan hak.

b. Budaya Hukum.

Faktor Budaya Hukum di Kota Yogyakarta, yakni perbedaan pemahaman konsep hukum di Pemerintah DIY khususnya Kantor Per- tanahan Kota Yogyakarta, masih kentalnya nilai ketertiban berupa ketaatan dan kemantapan hati masyarakat Yogyakarta bahwa semua titah Sultan bertujuan untuk ketentraman hidup bermasyarakat dan persepsi yang dari dulu hingga saat ini tertanam dalam benak warga Yogyakarta bahwa WNI Keturunan merupakan orang asing di Kota Yogyakarta.

c. Struktur Hukum.

Berdasarkan penelitian dilapangan melalui wawancara, Bapak Suhartono selaku Kepala Divisi Hak Atas Tanah dan Pendaftaran Hak Kantor Pertanahan Kota Yogyakarta memberikan tanggapannya atas Instruksi tahun 1975, seperti berikut:

"Instruksi tersebut merupakan bentuk diskriminasi positif (affirmative action) yang dibolehkan oleh undang-undang. Tujuannya tentu akan ada kedudukan yang sama antara Pribumi dan Keturunan, Yogyakarta ini istimewa, jadi ya tentu sah-sah saja jika ada aturan yang berbeda dibandingkan dengan daerah lain di Indonesia".

Merujuk dari hasil wawancara diatas, peniliti berpendapat bahwa Instruksi tersebut tidak bisa disebut sebagai kebijakan affirmative action (Sitorus, et al, 2006, 24). Sasaran larangan kebijakan tersebut saat ini bukannya menciptakan persamaan dalam kesempatan dan persamaan terhadap hasil yang dicapai, melainkan sikap yang menimbulkan perbedaan dalam memperoleh hak milik atas tanah di Kota Yogyakarta dan pemberlakuan Instruksi 1975 yang tanpa batas waktu. Komisi Nasional Hak Asasi Manusia RI dengan Nomor 037/R/ Mediasi/VIII/2014 menegaskan bahwa Instruksi tersebut tidak boleh lagi diberlakukan karena melanggar peraturan perundangundangan di atasnya.

Diantara ketiga faktor diatas, didapatkan faktor dominan yang mendasari sulitnya WNI Keturunan Tionghoa untuk mempunyai hak milik 
atas tanah karena faktor Budaya Hukum di Kota Yogyakarta, yakni perbedaan pemahaman konsep hukum di Pemerintah DIY khususnya Kantor Pertanahan Kota Yogyakarta terkait dengan kebijakan diskriminasi positif (affirmative action), masih kentalnya nilai ketertiban berupa ketaatan dan kemantapan hati masyarakat Yogyakarta bahwa semua titah Sultan bertujuan untuk ketentraman hidup bermasyarakat, serta persepsi yang dari dulu hingga saat ini tertanam dalam benak warga Yogyakarta bahwa WNI Keturunan merupakan orang asing di Kota Yogyakarta dan selalu memiliki finansial lebih tinggi dari warga pribumi.

Beberapa indikasi dalam budaya hukum tersebut yang akhirnya mengakibatkan penegakan substansi hukum yang terdapat dalam UUPA terkait dengan asas nasionalitas belum efektif. Perlu adanya pemahaman dalam masyarakat bahwa Instruksi tersebut bukan sebuah produk hukum yang secara otomatis tidak memiliki sifat mengikat seperti sanksi jika tidak dipenuhi, dan juga bukan sebuah kebijakan affirmative action sebagaimana yang sudah dijelaskan sebelumnya. sehingga nantinya akan berjalan seimbang antara hukum negara dan hukum yang berdasarkan kultur/ budaya Yogyakarta.

\section{Akibat Hukum dari Larangan Pemberian Hak Milik Atas Tanah Bagi WNI Keturunan Tionghoa}

Pemerintah Kota Yogyakarta yang masih memberlakukan Instruksi Kepala Daerah DIY PA.VIII/No.K.898/I/A/1975, menimbulkan perdebatan yang sangat pelik. Karena bagi seseorang, hak milik atas tanah sangat penting dan merupakan prinsip hukum yang berlaku dalam hubungan antara seseorang dengan lingkungan masyarakatnya, serta hak dari setiap warga negara, yang tidak bisa dihapus atau dihilangkan oleh pihak lain kecuali muncul situasi atau kondisi yang memaksa seseorang kehilangan haknya sesuai dengan peraturan perundang-undangan.
Namun prinsip hak milik sebagai hak setiap warga negara tidak seutuhnya berlaku di Kota Yogyakarta, sebagaimana pernyataan Bapak Suhartono: "memang benar adanya aturan larangan kepemilikan Hak Milik bagi WNI Keturunan Tionghoa. Dasar munculnya larangan tersebut karena pada saat itu kondisi ekonomi masyarakat pribumi jauh lebih lemah dibanding kondisi ekonomi masyarakat non Pribumi. Kemudian Sultan memiliki ketakutan jika tidak dibuat suatu kebijakan akan terjadi kesenjangan ekonomi yang merugikan rakyatnya (WNI Pribumi), maka demi keadilan dibuatlah Instruksi tersebut. Kantor Pertanahan juga selalu menyeleksi dengan cermat apakah pihak yang akan mendapatkan alas hak milik adalah WNI Pribumi atau bukan, kami melakukan seleksi mulai dari nama, alamat, dan data lainnya".

Pernyataan Bapak Suhartono yang menegaskan bahwa Instruksi tahun 1975 masih diberlakukan di Kota Yogyakarta, secara tidak langsung mengakibatkan terhambatnya pelaksanaan hak dan kewajiban yang harus dilakukan karena:

a. Pendaftaran tanah sebagai kewajiban yang harus dilakukan setelah memperoleh hak atas tanah melalui peralihan hak tidak dapat diproses oleh Kantor Pertanahan Kota Yogyakarta, dengan alasan bahwa WNI Keturunan Tionghoa bukan sebagai subyek hukum yang dapat mempunyai hak milik atas tanah di Kota Yogyakarta. Sedangkan kewajiban tersebut telah diatur dalam pasal 23 UUPA dan merupakan kewajiban bagi Pemerintah untuk menyelenggarakan pendaftaran tanah di seluruh Wilayah Republik Indonesia sebagaimana yang diatur dalam Pasal 19 Ayat (1) UUPA. Hambatan dalam hal pendaftaran tanah tersebut secara tidak langsung mengakibatkan tidak adanya kepastian hukum bagi WNI Keturunan Tionghoa untuk memperoleh hak milik atas tanah yang didapatkan melalui jual beli. 
b. Akta Jual Beli (selanjutnya disebut AJB) yang dibuat dan diajukan sebagai syarat permohonan proses balik nama hak atas tanah yang diperoleh melalui jual beli, oleh Kantor Pertanahan Kota Yogyakarta dianggap tidak sah dan dapat dibatalkan karena tidak memenuhi syarat subyektif.

"kami (Kantor Pertanahan Kota Yogyakarta) menolak permohonan proses balik nama sertifikat hak milik atas tanah, karena Instruksi tahun 1975 hanya memperbolehkan subyek hukum yang dapat mempunyai hak milik atas tanah adalah WNI Pribumi. Jadi walaupun semua syarat-syarat permohonan balik nama tersebut telah terpenuhi kami tetap tidak akan bisa memprosesnya. Kami menganggap bahwa AJB yang dilakukan tidak memenuhi syarat subyektif dan dapat dibatalkan karena WNI Keturunan Tionghoa tidak cakap hukum untuk dapat melakukan jual beli hak milik atas tanah di Kota Yogyakarta".

Penegasan terhadap subyek hukum yang dipersempit karena berlakunya Instruksi tahun 1975, menyebabkan WNI Keturunan Tionghoa menjadi tidak cakap hukum sebagai subyek yang dapat membuat perjanjian jual beli hak milik atas tanah. Bapak Suhartono menyatakan bahwa Kantor Pertanahan Kota Yogyakarta juga tidak ingin dipersalahkan terkait dengan AJB yang tidak diterima untuk proses balik nama, karena Kantor Pertanahan Kota Yogyakarta beranggapan bahwa Notaris/ PPAT lah yang lebih berperan penting sebagai penyaring awal untuk menentukan apakah pihak yang melakukan jual beli adalah seorang WNI Keturunan Tionghoa atau tidak.

Jika dianalisis secara substansi, Notaris / PPAT Kota Yogyakarta tidak salah jika membuatkan AJB para pihak terkait dengan hak milik atas tanah yang diperoleh melalui jual beli. Karena pada pemberian status hak dengan balik nama, tentu harus ada perbuatan hukum di atas hak tersebut bisa melalui jual beli, sewa menyewa, tukar menukar, hibah, waris, lelang, merger dan pemasukan dalam inbreng (Adrian, 2012, 217). Namun akibat pemberlakuan Instruksi tahun 1975 di Kota Yogyakarta, maka AJB yang dibuat oleh Notaris/ PPAT tersebut menjadi tidak memiliki kekuatan pembuktian sempurna dan dapat dibatalkan karena salah satu pihak dianggap tidak cakap hukum untuk melakukan jual beli.

Lempar tanggung jawab antara Kantor Pertanahan Kota Yogyakarta dan Notaris/ PPAT, mengakibatkan tidak adanya perlindungan hukum bagi WNI Keturunan Tionghoa terkait dengan hak milik yang telah dibeli. Jalan keluar yang biasa dilakukan di Kantor Pertanahan Kota Yogyakarta seperti yang terdapat dalam analisis sub bab pertama penelitian ini yaitu, jika WNI Keturunan Tionghoa tetap ingin memperoleh hak atas tanah harus melakukan pemindahan hak, yaitu dengan proses penyerahan/ pelepasan hak atau dengan penurunan hak.

Kedua, prosedur yang harus dilakukan oleh WNI Keturunan Tionghoa apabila ingin memperoleh hak atas tanah yang telah dibelinya hanya dengan melalui pelepasan hak atau penurunan hak, Instruksi Kepala Daerah DIY tahun 1975 juga mengakibatkan ketentuan terkait dengan pelayanan pertanahan bagi WNA yang terdapat di dalam pasal 21 ayat (3) UUPA juga diberlakukan bagi WNI Keturunan Tionghoa di Kota Yogyakarta:

a. Pewarisan/ hibah kepada mereka yang tidak memenuhi persyaratan sebagai pemegang hak milik atas tanah (subyeknya), diberikan jangka waktu selama 1 (satu) tahun untuk mengalihkan hak milik tersebut kepada orang lain;

b. Ketentuan lain menerangkan bahwa terhadap WNA dimungkinkan menjadi pemegang hak atas tanah di Indonesia dengan status hak pakai, sesuai peruntukan tanah tersebut. 
Kantor Pertanahan Kota Yogyakarta melalui Bapak Suhartono menyatakan apabila ada AJB yang dilakukan dengan salah satu pihak adalah WNI Keturunan, maka apapun permohonan haknya jika terkait perolehan hak milik atas tanah tidak akan diproses sebagaimana biasanya. Pernyataan Bapak Suhartono tersebut membuktikan bahwa AJB yang dikatakan tidak memenuhi syarat subyektif tersebut, dalam pelaksanaan pembatalannya ternyata tidak melalui pengadilan sebagaimana yang diatur dalam hukum perjanjian. Jadi menurut Ibu Diah dan Bapak Bambang selaku Notaris dan PPAT di Kota Yogyakarta penentuan bahwa AJB tersebut tidak berlaku berbarengan dengan saat dikeluarkannya surat keputusan penolakan oleh Kantor Pertanahan, terkait permohonan balik nama sertifikat hak milik atas tanah yang diperoleh melalui jual beli.

Persepsi yang tumbuh dan telah lama tertanam pada aparat hukum di Kantor Pertanahan Kota Yogyakarta sangat berbanding terbalik dengan konsep/ makna dari cakap hukum didalam ilmu hukum. Cakap hukum itu terkait dengan kecakapan subyek hukum, yakni kecakapan berhak (Rechtsbevoegd) dan kecakapan bertindak (Handelingsbekwaam) untuk melaksanakan hak-hak dan kewajiban yang diatur oleh hukum.

Jika dianalisis berdasarkan kasus pada permasalahan yang terdapat pada penelitian ini sebenarnya adalah WNI Keturunan Tionghoa kehilangan kecakapan berhak (Rechtsbevoegd) untuk dapat memperoleh haknya sebagai warga negara yaitu mempunyai hak milik atas tanah di Indonesia. Kekeliruan pemahaman konsep antara kecakapan berhak (Rechtsbevoegd) dan kecakapan bertindak (Handelingsbekwaam) yang terjadi di Kantor Pertanahan Kota Yogyakarta, harus segera diakhiri karena secara tidak langsung mengganggu subyek hukum untuk melaksanakan hak-hak dan kewajiban yang sudah diatur oleh hukum. Terutama dengan hak milik yang diperoleh melalui jual beli, dimana WNI Keturunan Tionghoa terikat dengan hak serta kewajiban yang akan didapat dan yang harus dilakukan, agar perbuatan hukum berupa jual beli tersebut sah menurut hukum (Santoso, 2014, 54).

Benturan aspek keadilan dan kepastian yang terjadi dalam hal pertanahan di Kota Yogyakarta harus segera diselesaikan dengan mencari jalan keluar seperti revisi substansi isi Instruksi Kepala Daerah DIY tahun 1975 sehingga ada perlindungan hukum bagi masyarakat Yogyakarta tanpa membedakan Pribumi ataupun Keturunan.

\section{Upaya Memberikan Perlindungan Hukum Bagi WNI Keturunan Tionghoa Guna Memperoleh Hak Milik}

Paul Scholten $(1986,20)$ mengungkapkan bahwa perlindungan hukum itu tidak bisa dipisahkan dari hukum subyektif, artinya suatu hukum tidak hanya ditujukan untuk satu kewenangan saja, melainkan terdapat beberapa kewenangan dalam satu kelompok yang harus diperlakukan sebagai satu kesatuan tanpa terpisah. Philipus M. Hadjon $(1987,20)$ berpendapat bahwa prinsipprinsip perlindungan hukum bagi rakyat di Indonesia adalah prinsip pengakuan dan perlindungan terhadap harkat martabat manusia yang bersumber pada Pancasila serta hukum yang juga berdasarkan pada pancasila. Hestu Cipto Handoyo dalam sosialisasi Undang-Undang Kewarganegaraan berpendapat bahwa Undang-Undang Kewarganegaraan tahun 2006 mengajarkan kita untuk menghilangkan stigma pribumi dan non pribumi.

Prinsip Nasionalitas dalam UUPA juga dipertegas oleh UU HAM pasal 36 yang intinya menyatakan bahwa setiap orang berhak untuk mempunyai hak milik baik sendiri ataupun bersama-sama demi pengembangan dirinya, keluarga, bangsa dan masyarakat dengan tidak melanggar hukum. Komnas HAM RI berpendapat bahwa pencabutan hak milik atas suatu benda demi kepentingan umum hanya diperbolehkan dengan meng- 
ganti kerugian dan sesuai ketentuan peraturan perundang-undangan. Paul Scholten juga berpendapat bahwa hak milik itu primer artinya setiap orang menurut kewenangannya jika dipandang secara umum boleh menguasai serta berbuat sesuatu atas barangnya, tetapi dengan batasan-batasan hukum (Siti, 1986, 20). Penjabaran atas teori perlindungan hukum tersebut dipertegas oleh Bapak Dahlan selaku Dosen HAN/ HTN FH UB, yaitu:

"menurut Paul Scholten suatu hak milik seseorang itu sama nyatanya dengan sekumpulan masyarakat yang diatur dalam hukum, namun tidak bisa lebih dari itu. Karena suatu hukum didalamnya mengharuskan untuk mengatur pembatasan atas hak milik seseorang. Dimana arti pembatasan tersebut dalam suatu waktu bisa berbeda-beda".

Artinya Negara berhak untuk mengaturnya dalam sebuah hukum juga terkait dengan pembatasan-pembatasan atas kebebasan hak milik seseorang, dengan ketentuan bahwa pembatasan tersebut tidak merugikan dan memang untuk kepentingan bersama. Tapi pembatasan tersebut tidak bisa diperluas yang menyebabkan seseorang atau suatu kelompok yang karena perluasan tersebut mengakibatkan kehilangan hak mutlaknya atas hak milik.

Isi dari Instruksi tersebut tentunya Pemerintah Daerah Provinsi DIY telah memperluas pembatasan-pembatasan hak milik seseorang, sehingga seseorang ataupun suatu kelompok kehilangan haknya untuk mendapatkan hak milik. Jadi tidak heran timbul konflik internal antara WNI Pribumi dan WNI Keturunan Tionghoa, dimana satu sisi WNI Pribumi menganggap bahwa pemerintah Yogyakarta telah melindungi hak-hak mereka sedangkan WNI Keturunan Tionghoa beranggapan bahwa pemerintah Yogyakarta telah merampas hak-hak mereka untuk memiliki hak milik atas tanah.

Beberapa upaya hukum yang telah dilakukan oleh WNI Keturunan Tionghoa pun tidak menda- patkan hasil, sedangkan teori hukum progresif yang diajarkan oleh Satjipto Rahardjo menyatakan bahwa pemerintah dalam membuat suatu peraturan memang diharuskan untuk selalu berlandaskan pada hukum yang pro keadilan dan pro rakyat, namun pemerintah tidak bisa berhenti disitu melainkan harus menganlisis akibat hukum dari pemberlakuan praturan yang telah dibuat tersebut. Maka dari itu sudah seharusnya Gubernur DIY melakukan revisi terkait dengan substansi/ isi dari Instruksi Kepala Daerah DIY tahun 1975 ke sebuah peraturan daerah yang tetap memberikan WNI Keturunan Tionghoa hak untuk dapat mempunyai hak milik atas tanah di DIY, tetapi dengan tetap menggunakan pembatasan seperti maksimal luas tanah yang hanya bisa dibeli tentunya setelah berkoordinasi dengan Kementerian Agraria dan Tata Ruang RI. Perubahan substansi tersebut dirasa lebih tepat karena WNI Pribumi dan WNI Keturunan Tionghoa akhirnya memiliki kesempatan yang sama untuk dapat meningkatkan taraf hidup masing-masing dan menikmati hak konstitusional mereka sebagai WNI di Kota Yogyakarta.

\section{Penutup \\ Kesimpulan}

Faktor dominan yang mendasari sulitnya WNI Keturunan Tionghoa untuk mempunyai hak milik atas tanah disebabkan oleh faktor Budaya Hukum di Kota Yogyakarta, yakni perbedaan pemahaman konsep hukum di Kantor Pertanahan Kota Yogyakarta, kentalnya nilai ketertiban berupa ketaatan dan kemantapan hati masyarakat Yogyakarta bahwa semua titah Sultan bertujuan untuk ketentraman hidup bermasyarakat dan persepsi masyarakat Yogyakarta bahwa WNI Keturunan merupakan orang asing di Kota Yogyakarta.

Pemberlakuan Instruksi Kepala Daerah DIY PA.VIII/No.K.898/I/ A/1975 menimbulkan dua sisi yang bertentangan, jika dilihat pada tujuan pembentukannya Instruksi tersebut sebenarnya 
memberikan perlindungan kepada WNI Pribumi agar terhindar dari penguasaan masif pihak-pihak yang berfinansial tinggi. Namun pada satu sisi menimbulkan ketidakpastian hukum dalam hal pertanahan di Kota Yogyakarta, karena dua aturan hukum diberlakukan pada subyek hukum yang sama sehingga menyebabkan terhambatnya pelaksanaan hak dan kewajiban berupa kewajiban untuk melalukan pendaftaran tanah dan WNI Keturunan Tionghoa diharuskan melakukan pelepasan hak atau penurunan hak. apabila ingin menikmati hak atas tanah yang telah didapat melalui jual beli.

Instruksi Kepala Daerah DIY PA.VIII/ No.K.898/I/ A/1975 pada dasarnya bertujuan demi keadilan agar WNI Pribumi mempunyai kesempatan yang sama dalam meningkatkan taraf hidup dengan mempunyai hak milik atas tanah di Kota Yogyakarta. Namun dalam pelaksanaannya pemberlakuan Instruksi tersebut diperluas dan menimbulkan akibat dimana seseorang/ bahkan kelompok (WNI Keturunan Tionghoa) kehilangan hak konstitusionalnya sebagai warga negara untuk dapat mempunyai hak milik atas tanah, sehingga upaya yang seharusnya dilakukan Gubernur DIY dalam memberikan perlindungan hukum bagi masyarakatnya yaitu dengan merubah substansi Instruksi Kepala Daerah DIY tahun 1975 dan diganti dengan sebuah peraturan daerah yang tetap memberikan WNI Keturunan Tionghoa hak untuk dapat mempunyai hak milik atas tanah di DIY, tetapi dengan tetap menggunakan pembatasan seperti maksimal luas tanah yang hanya bisa dibeli tentunya setelah berkoordinasi dengan Kementerian Agraria dan Tata Ruang RI. Perubahan substansi tersebut dirasa lebih tepat karena WNI Pribumi dan WNI Keturunan Tionghoa akhirnya memiliki kesempatan yang sama untuk dapat meningkatkan taraf hidup masing-masing dan menikmati hak konstitusional mereka sebagai WNI di Kota Yogyakarta.

\section{Saran}

Konsisten terhadap penerapan UUPA dalam hal pelayanan pertanahan tanpa memberlakukan lagi aturan yang menghilangkan hak konstitusional seorang warga negara dan bertentangan dengan Undang-undang di atasnya, sehingga peraturan tersebut dapat mewujudkan tujuan hukum yang sebenarnya yakni keadilan, kepastian dan kemanfaatan. WNI Keturunan (Tionghoa, Arab, India, dan Ekspatriat Asing) yang bertempat tinggal di Yogyakarta adalah WNI dan bukan orang asing tanpa membedakan WNI Pribumi ataupun Keturunan. WNI Keturunan (Tionghoa, Arab, India, dan Ekspatriat Asing) di Yogyakarta, agar lebih memahami hak dan kewajiban yang dimiliki oleh masing-masing warga negara untuk dapat mempunyai hak milik atas tanah di seluruh Indonesia sehingga tidak muncul lagi paham rasial terkait golongan berdasarkan ras atau etnis. Kementerian Agraria dan Tata Ruang Republik Indonesia, agar lebih berperan aktif dalam melakukan pengawasan jalannya peraturan perundang-undangan, serta memberikan penyuluhan hukum terhadap daerahdaerah mengenai kewenangan yang terdapat didalam otonomi daerah apa saja.

\section{DAFTAR PUSTAKA}

\section{Buku}

Ali, Ahmad, 2009, Menguak Teori Hukum (Legal Theory) E Teori Peradilan (Judicial Prudence) Termasuk Interprestasi Undang-Undang (Legisprudence), Kencana Prenada Media Group, Jakarta.

Hadjon, Philipus M., 1987, Perlindungan Hukum Bagi Rakyat Indonesia, PT Bina Ilmu, Surabaya.

Harsono, Boedi, 2008, Hukum Agraria Indonesia: Sejarah Pembentukan Undang-undang Pokok Agraria, Isi dan Pelaksanaannya, Djambatan, Jakarta.

Hartono, Siti Soemarti, 1986, Mr. C. Asser Penuntun dalam Mempelajari Hukum Perdata Belanda: Bagian Umum, Gadjah Mada University Press, Yogyakarta. 


\section{Jurnal Cakrawala Hukum}

Vol.7, No.2 Desember 2016: 247-256

Hutagalung, Arie Sukanti, 2012, Hukum Pertanahan di Belanda dan Indonesia, Pustaka Larasan, Jakarta.

Kamelo, Tan, 2006, Hukum Jaminan Fidusia Suatu Kebutuhan yang Didambakan, Alumni, Bandung.

Muliawan, 2009, Pemberian Hak Milik Untuk Rumah Tinggal, Cerdas Pustaka, Jakarta.

Rahardjo, Satjipto, 1996, Ilmu Hukum, Citra Aditya Bakti, Bandung.

Rasjidi, Lili, dan Putra, I.B Wysa, 1993, Hukum Sebagai Suatu Sistem, Remaja Rusdakarya, Bandung.

Sahat, 2007, Jual Beli Tanah dan Pencatatan Peralihan Hak, Pustaka Sutra, Bandung.

Setiawati, Nur Aini, 2011, Dari Tanah Sultan Menuju Tanah Rakyat, STPN Press, Sleman Yogyakarta.

Sitorus, Oloan dan Sierrad, Zaki, 2006, Hukum Agraria di Indonesia - Konsep Dasar dan Implementasi, Mitra Kebijakan Tanah Indonesia, Yogyakarta.

Soekanto, Soerjono, 1983, Beberapa Aspek Sosio Yuridis Masyarakat, Alumni, Bandung.

Subekti, 2002, Hukum Perjanjian, Intermasa, Jakarta.

Sunarso, Siswantoro, 2010, Penegakan Hukum Psikotropika dalam Kajian Sosiologi Hukum, Raja Grafindo Persada, Jakarta.

\section{Artikel Ilmiah/ Karya Ilmiah}

Hendras Budi Paningkat, 2008, Implementasi UU Nomor 12 Tahun 2006 Pada Pemberian Hak Atas Tanah Bagi WNI Keturunan Tionghooa di Kota Yogyakarta Provinsi Daerah Istimewa Yogyakarta, Sekolah Tinggi Pertanahan Nasional, Yogyakarta.
Komisi Nasional Hak Asasi Manusia, 2013, Rekomendasi Terkait Dengan Diskriminasi Hak Atas Tanah Warga Keturunan Tionghoa di Provinsi Daerah Istimewa Yogyakarta, Yogyakarta.

Widhiana Hestining Puri, 2013, Kontekstualitas Affirmative Action dalam Kebijakan Pertanahan di Yogyakarta, Yogyakarta: Bhumi Jurnal Ilmiah Pertanahan PPPM-STPN.

Ariesta Budi Rahayu, 2014, Mengulik Siasat Kepemilikan Tanah Berstatus Hak Milik Bagi Warga Keturunan China di Yogyakarta Berdasarkan Instruksi Gubernur DIY PA VIII No.K.898/I/A/1975, Program Magister Kenotariatan Universitas Gadjah Mada, Yogyakarta.

Hasbi Ash Siddiqy Vad'aq, 2015, Larangan Kepemilikan Tanah Bagi Warga Negara Indonesia Non Pribumi Untuk Keturunan Arab di Daerah Istimewa Yogyakarta Berdasarkan Instruksi Gubernur DIY PA VIII No.K.898/ I/A/1975, Program Magister Kenotariatan Universitas Gadjah Mada, Yogyakarta.

\section{Peraturan Perundang-Undangan}

Undang-Undang Dasar Negara Republik Indonesia 1945.

Undang-Undang Nomor 5 Tahun 1960 tentang Peraturan Dasar Pokok-pokok Agraria.

Undang-Undang Nomor 12 Tahun 2006 tentang Kewarganegaraan Republik Indonesia.

Instruksi Kepala Daerah Istimewa Yogyakarta Nomor: K.898/I/A/1975 tentang Penyeragaman Policy Pemberian Hak Atas Tanah Kepada Seorang WNI Non Pribumi.

Peraturan Menteri dalam Negeri Nomor: 54 Tahun 2009 tentang Tata Naskah Dinas di Lingkungan Pemerintah Daerah. 